\title{
Co-producing Across Organisational Boundaries: Promoting Asylum Seeker Integration in Scotland
}

\author{
Kirsty Strokosch ${ }^{1}$ (D) Stephen P. Osborne ${ }^{1}$
}

Published online: 12 December 2016

(C) The Author(s) 2016. This article is published with open access at Springerlink.com

\begin{abstract}
This paper questions whether asylum seeker integration is promoted through inter-organisational relationships between non-profit and voluntary organisations (NPVOs) and government agencies. It focuses particularly on the role of NPVOs in service delivery (co-management) and in the delivery and planning of public services (co-governance). It presents a research study on the public services provided to asylum seekers in Glasgow and asks the following questions: What role do NPVOs play in the planning and delivery of public services? When planning and delivering public services, to what extent do NPVOs work across organisational boundaries and what kind of relationships exist? And in practice, what makes interorganisational relationships work? This paper offers new empirical evidence and also contributes to the theoretical debate around the integration of asylum seekers.
\end{abstract}

Résumé Le présent article cherche à savoir si l'intégration des demandeurs d'asile est favorisée par les relations qui existent entre les organisations bénévoles sans but lucratif et les organismes gouvernementaux. Il se penche particulièrement sur le rôle des organismes bénévoles dans les domaines de la prestation de services (cogestion) et de la prestation et la planification des services publics (co-gouvernance). Il présente une étude de recherche sur les services publics fournis aux demandeurs d'asile de Glasgow. Celle-ci pose les questions suivantes: «Quel rôle les organismes bénévoles sans but lucratif jouent-ils dans la planification et la prestation des services publics? »; «S'ils planifient et offrent lesdits services publics, dans quelle mesure ces organismes œuvrent-ils avec diverses organisations et quels types de relations sont en place? »; et «Dans la pratique, qu'est-ce qui assure la réussite des relations interorganisationnelles? $»$ Le présent article offre de nouvelles preuves

Kirsty Strokosch

kirstystrokosch@hotmail.com

1 Centre for Service Excellence, University of Edinburgh Business School, 29 Buccleuch Place, Edinburgh EH8 9JS, UK 
empiriques et contribue également au débat théorique entourant l'intégration des demandeurs d'asile.

Zusammenfassung Diese Abhandlung beschäftigt sich mit der Frage, ob die Integration von Asylsuchenden durch organisationsübergreifende Beziehungen zwischen gemeinnützigen und ehrenamtlichen Organisationen einerseits und Regierungsbehörden andererseits gefördert wird. Man konzentriert sich insbesondere auf die Rolle der gemeinnützigen und ehrenamtlichen Organisationen bei der Dienstleistungsbereitstellung (Co-Management) und bei der Bereitstellung und Planung öffentlicher Dienstleistungen (Co-Regierung). Der Beitrag präsentiert eine Forschungsstudie zu den öffentlichen Dienstleistungen für Asylsuchende in Glasgow und geht auf folgende Fragen ein: Welche Rolle spielen gemeinnützige und ehrenamtliche Organisationen bei der Planung und Bereitstellung öffentlicher Dienstleistungen? In welchem Umfang arbeiten gemeinnützige und ehrenamtliche Organisationen im Rahmen der Planung und Bereitstellung öffentlicher Dienstleistungen über die Grenzen ihrer Organisationen hinaus und welche Art von Beziehungen unterhalten sie? Wie funktionieren organisationsübergreifende Beziehungen in der Praxis? Diese Abhandlung liefert neue empirische Beweise und leistet zudem einen Beitrag zur theroretischen Debatte über die Integration von Asylsuchenden.

Resumen El presente documento se pregunta si la integración del solicitante de asilo se promueve mediante relaciones interorganizativas entre las organizaciones voluntarias y sin ánimo de lucro (NPVO, por sus siglas en inglés) y las agencias gubernamentales. Se centra en particular en el papel de las NPVO en la entrega de servicios (cogestión) y en la entrega y planificación de servicios públicos (cogobernanza). Presenta un estudio de investigación sobre los servicios públicos proporcionados a solicitantes de asilo en Glasgow y realiza las siguientes preguntas: ¿qué papel desempeñan las NPVO en la planificación y entrega de servicios públicos?; cuando se planifican y entregan servicios públicos, ¿en qué medida las NPVO trabajan más allá de las fronteras organizativas y qué tipo de relaciones existen?; y en la práctica, ¿qué hace que funcionen las relaciones interorganizativas? El presente documento ofrece nuevas evidencias empíricas y contribuye también al debate teórico en torno a la integración de solicitantes de asilo.

Keywords Inter-organisational relationships · Asylum seekers · Non-profit and voluntary organisations · Integration

\section{Introduction}

Although inter-organisational relationships are not new, with the literature dating back to the 1960s (e.g. Aiken and Hage 1968; Pfeffer and Nowak 1976), there has been an increased focus on joint working over the past twenty years which has led to developments in the conceptualisation and practice of public services management. 
A strong government push for inter-organisational relationships through partnership, collaboration, networks and joint working are notable across Europe.

This paper will question whether asylum seeker integration is fostered through inter-organisational relationships between non-profit and voluntary organisations (NPVOs) and government agencies. NPVOs can take two roles: they can contribute to service delivery (co-management) or to both the delivery and planning of public services (co-governance) (Brandsen and Pestoff 2006). By presenting the findings from a study of asylum seekers living in Glasgow, we will consider the following subquestions: What role do NPVOs play in the planning and delivery of public services? When planning and delivering public services, to what extent do NPVOs work across organisational boundaries and what kind of relationships exist? And in practice, what makes inter-organisational relationships work? This paper will offer new empirical evidence and will also contribute to the theoretical debate around the integration of asylum seekers in their host country.

\section{Asylum Seekers, Integration and NPVOs}

Asylum seekers sit in a contentious position, having exercised their legal right under the Geneva Convention (1951) to apply for asylum, but remaining non-citizens while they await the outcome of their case. During this time, they are regulated and constrained by strict immigration laws which have been fabricated around a strong policy of deterrence (Wren 2007). Although the Scottish Government promotes the integration of asylum seekers into Scottish society as soon as they arrive in the country (rather than if and when they receive refugee status, as is the case in the UK), the political, social and legal backdrop makes integration particularly challenging (Bloch 2000).

The concept of integration has multiple meanings. Ager and Strang (2008) propose a framework to summarise what constitutes successful integration. They specify various core domains including access to employment, housing, education and health; social connections in the community, including ethnic or religious identity; social bonds with members of other communities; social links with institutions; safety and security; and language and cultural knowledge.

Asylum seekers are positioned as a disempowered and marginalised group who are not bestowed the same benefits and access rights as others in society and are therefore not privy to each of Ager and Strang's core domains. Asylum seekers have access to various public services including education, health and housing, although they tend to be placed in socially deprived areas (Sim and Bowes 2007). They are, however, prevented from engaging in policy-making processes (Haikio 2010) and their residence in the country of asylum is governed by a stratified system of social rights which forbids them from working for remuneration. This paper will discuss whether any of Ager and Strang's elements of integration are promoted through NPVOs working across organisational boundaries to produce public services.

Historically, NPVOs have played a leading role in supporting asylum seeker integration in Scotland, responding on an ad hoc basis to individual crises and establishing support programmes (Wren 2007). The Race Equality Statement 
situates the NPVS in a core position, referring to it as a 'strategic partner' (Scottish Government 2008) that provides specialist expertise and service provision. However, according to Griffiths et al. (2006), the role of gap filling and meeting basic needs rather than active involvement in the development of policies, potentially situates NPVOs on the periphery and may hinder asylum seeker integration. This leads to our first subquestion: what role do NPVOs play in the planning and delivery of public services?

As mediating structures (Berger and Neuhaus 1978), NPVOs can facilitate the inclusion of marginal groups, who do not have the necessary resources, capacity or power to articulate their own need (Kearns 1995; Haugh and Kitson 2007). They can help asylum seekers access the public services, but NPVOs cannot necessarily be equated with greater participation because this depends on whether the decisionmaking structures of the organisation promote participation (Pestoff 2012). There is an ongoing debate about whether the involvement of NPVOs in public service production genuinely enhances co-production and integration, through the strength of collective action, or actually diminishes it by placing the organisation between the individual service users and service providers (Brenton, 1985; Bloch and Schuster 2002; Sales 2002; Pestoff et al. 2006).

Due to the complexity of their needs, a multi-agency approach has been fundamental to supporting asylum seekers (Scottish Government 2006) which leads to our second subquestion: when planning and delivering public services, to what extent do NPVOs work across organisational boundaries and what kind of relationships exist?

The Scottish Compact, first published in 1998 and revised in 2003, sets out the particulars of the agreement in Scotland which elevates the NPVS as a key 'partner' involved in the decision-making process. Community Planning also places the NPVS in a prominent role. It provides the underpinning framework for partnership and co-ordination within complex environments. The Local Government in Scotland Act 2003 placed responsibility on Local Authorities to undertake Community Planning and in doing so, genuinely engage communities in decisionmaking process. A new relationship between the Scottish Government and Local Government was set out in the Concordat in 2007, which required each Local Authority to develop a Single Outcome Agreement (SOA). Since 2009-10, all SOAs were developed with the full involvement of respective Community Planning Partnerships, including NPVOs.

\section{Inter-organisational Relationships: Co-management and Co-governance}

Brandsen and Pestoff (2006) differentiate the inter-organisational relationship, suggesting that two relationships exist: co-management and co-governance.

Co-management operates at the meso-level (Pestoff 2012) and describes instances where NPVOs contribute to public service delivery (Brandsen and Pestoff 2006; Pestoff et al. 2006). Such relationships are typically governed by contracts (Tsukamoto and Nishimura 2006; Bode 2006). The contractual relationship makes clear a division of labour, with responsibility for service delivery falling to the 
NPVOs while the government controls the purse strings. The government's day-today interaction with public service users is therefore reduced, with NPVOs delivering services acting as a buffer (Schmid 2003).

A concern of working under government contracts is the potential for the NPVO's role, distinctive characteristics and original values to be diluted by the government agency funding them (Berger and Neuhaus 1978; Deakin 2001; Bode 2006). Furthermore, NPVOs may be apprehensive of acting in opposition to government if this will influence their likelihood to win contracts, potentially impacting their adversarial role. However, Brandsen and von Hout (2006) argue that co-management does not necessarily result in a loss of autonomy because organisations can contribute to policy changes through implementation by shaping services according to local needs.

The term co-governance has been coined to describe the role of NPVOs in policy formation and community governance (Vidal 2006; Kelly 2007; Brandsen and Pestoff 2006; Pestoff 2012). Co-governance introduces an opportunity for NPVOs to bring their interests and agendas into the realm of planning by contributing to the governance of public services through, for example, Voluntary Sector Compacts and Local Strategic Partnerships. Thus, decision-making capacity becomes increasingly dispersed across actors (Morison 2000). This leads Somerville and Haines (2008) to argue that co-governance has the potential to enhance democratic accountability, resulting in fairer and more effective decision-making.

Inter-organisational relationships through network approaches have been described as reliant on the existence of credibility, reputation, reciprocity and trust among members (Vidal 2006; Newman 2007). Indeed, the process of working in networks involves bringing together expertise, knowledge and resources from across sectors as a way of tackling complex problems and improving services (Brandsen and von Hout 2006). This involves interaction between multiple actors who are mutually dependent and reliant on one another's resources (e.g. financial, political or informational) (Rhodes 1997). Interdependence means that co-operation is essential, although it does not preclude conflict. Each actor takes its own perspective, creating tension between dependency and the diversity of goals and interests. The success and failure are thus based upon the extent to which cooperation is achieved on a day-to-day basis (Klijn and Koppenjan 2000; Klijn 2008). For Sicilia et al. (2016), building and sustaining trust over time was fundamental to ensuring the collaboration of families and non-profit organisations. These actors were involved throughout the policy process and service cycle in order to foster trusting relationships.

The literature on networks and governance discusses the changed role of public services' managers as one that is dependent upon building and sustaining relationships across organisational boundaries (Brandsen and von Hout 2006). It is around the management of these inter-organisational relationships that theory from the services management literature provides valuable insight and it is here where our final subquestion arises: in practice, what makes inter-organisational relationships work?

The services management literature suggests that inter-personal relationships and trust are fundamental to inter-organisational exchanges (Ring and Van de Ven 1992; 
Gulati 1995; Zaheer et al. 1998). Trust operates at the level of individuals (Kale et al. 2000) and personal relationships are therefore fundamental to shaping interorganisational relationships by determining the level of co-operation that exists (Ring and Van de Ven 1992; Zaheer et al. 1998). However, conflict can result between the personal and formal relationships. Nooteboom et al. (1997) suggest that co-operation based on trust through inter-personal relationships may cause loyalty to deviate from organisational interests, and furthermore, that staff turnover may result in a breakdown in relations between organisations due to a loss of personal trust.

\section{Methodology}

Glasgow was the only local authority area in Scotland to enter into a contract with the UK Government to provide accommodation for asylum seekers dispersed to Scotland. This sets clear geographical boundaries for the study, which took a mixed methods approach, consisting of policy interviews, a small-scale survey, an embedded case study design of Glasgow and stakeholder interviews.

In-depth policy interviews were conducted with seven key national and city-wide organisations, selected through the use of a purposive sampling technique. The respondents are detailed in Table 1 as follows:

A Glasgow-wide postal survey of service managers in those organisations providing social welfare services to asylum seekers was conducted. In total, 107 questionnaires were distributed. The questionnaires were sent to named individuals where possible and were coded to keep track of and chase up non-responses. In total, 43 completed questionnaires were returned, providing a reasonable response rate of 40 per cent. As a result, the analysis was limited to descriptive statistics.

An embedded case study design was adopted to take a concentrated focus on the city of Glasgow. A mixture of community-based and large NPVOs and statutory agencies were selected to generate different discourses and a detailed account of the context through various interviews and observations. In addition, two core structures in the provision of social welfare services for asylum seekers were investigated: Framework for Dialogue Groups and Integration Networks. Table 2 provides the further details.

The interviews that did not progress to sub-units within the case study design were valuable and reliable sources of data and were therefore included in the analysis as contextual stakeholder interviews (see Table 3 below).

\section{Findings}

\section{What Role Do NPVOs Play in the Planning and Delivery of Public Services?}

When asked whether they represent asylum seekers to public service providers, over half of respondents responded positively $(54.8 \%)$. The majority of these respondents agreed to some extent ( $86.52 \%)$ that their knowledge of asylum seekers was 'valued 
Table 1 Policy respondents

\begin{tabular}{ll}
\hline Policy respondents & Role \\
\hline Scottish Government Policy 1 & NPVS policy \\
Scottish Government Policy 2 & Asylum seeker policy \\
Scottish Government Policy 3 & Asylum seeker policy \\
UK Government Agency & Immigration policy at the UK level \\
Charity Manager & Policy and operations of the Charity \\
Accommodation Manager Strategic Manager & Policy and operations of the Accommodation Provider \\
Community Planning Partnership Manager & Community Planning \\
\hline
\end{tabular}

by service providers'. A similar proportion (82.59\%) also agreed to some extent that 'Service providers listen to what I have to say because I'm acting on behalf of service users'. Nearly, two-thirds of respondents (65.52\%) disagreed to some extent with the following statement: 'Service providers don't act on the advice I give them'. Finally, $82.6 \%$ of respondents in this section agreed to some extent that 'Asylum seeker voices are represented by the organization I work for'.

The case study also showed high regard for NPVOs among policy makers who generally viewed them as adding value to public services and contributing to their effectiveness. The overwhelming argument was that the NPVS played a fundamental role in creating dialogue between asylum seekers and public service providers/policy makers.

People who... are quite vulnerable and might not necessarily trust the state or indeed the private sector. But the third sector can actually effectively reach out to these people and can transform their lives, and have an effective track record of being able to do that... (Scottish Government Policy 3)

In particular, the view of the Charity was very positive. Respondents were generally at pains to explain the importance of their role as mediator due to their close links and knowledge of asylum seekers in Glasgow. The Charity was viewed as supporting the inclusion of asylum seekers and Refugee and Community Organisations. It was portrayed a key link in the chain, bonding organisations on the ground with strategic players: '[The Charity] are very involved with the Government... we get information back and that information that our group gathers gets fed back through that structure as well. (Young Person's Group)'

Data gathered from Church A, Church B, the Young Person's Group, Development Organisation and Humanitarian Organisation highlighted integration to be an underpinning goal of the services. Church A, for example, offered drop-in sessions, craft groups and English classes and the service manager described these as offering a 'social and safe environment' where asylum seekers can 'integrate and socially interact'. The survey findings also suggested that integration was associated to the services being provided. 
Table 2 Case study sub-units

\begin{tabular}{|c|c|c|}
\hline Sub-units & Case description & Methods used \\
\hline Church A & $\begin{array}{l}\text { Small community organisation providing various } \\
\text { services to asylum seekers (AS), e.g. drop-in } \\
\text { sessions for women and children and English } \\
\text { classes. }\end{array}$ & $\begin{array}{l}\text { Service manager interview } \\
\text { Observation }\end{array}$ \\
\hline Church B & $\begin{array}{l}\text { Small community organisation providing services } \\
\text { to AS, including computer and English classes. } \\
\text { Also provides ad hoc support and signposts to } \\
\text { other services. }\end{array}$ & $\begin{array}{l}\text { Service manager interview } \\
\text { Observation }\end{array}$ \\
\hline $\begin{array}{l}\text { Accommodation } \\
\text { provider }\end{array}$ & $\begin{array}{l}\text { Public sector organisation responsible for housing } \\
\text { asylum seekers in Glasgow under a contract } \\
\text { with the Government Agency. }\end{array}$ & $\begin{array}{l}\text { Service manager interview } \\
\text { Strategic Manager interview } \\
\text { Government Agency interview } \\
\text { Observation }\end{array}$ \\
\hline $\begin{array}{l}\text { Humanitarian } \\
\text { Organisation }\end{array}$ & $\begin{array}{l}\text { National organisation developed services in } \\
\text { response AS dispersal, such as an International } \\
\text { Tracing Service; Orientation Service; } \\
\text { Newspaper; volunteer drop-in sessions; and } \\
\text { outreach work with schools. }\end{array}$ & $\begin{array}{l}\text { Service manager interview } \\
\text { Front-line staff interview }\end{array}$ \\
\hline $\begin{array}{l}\text { Development } \\
\text { Organisation }\end{array}$ & $\begin{array}{l}\text { City-wide organisation that offered services to AS, } \\
\text { including Adult Literacy and Numeracy classes. } \\
\text { A broader aim was to help underrepresented } \\
\text { groups (e.g. asylum seekers) find volunteering } \\
\text { opportunities. }\end{array}$ & $\begin{array}{l}\text { Service Manager interview } \times 2 \\
\text { Front-line staff interview (duo) } \\
\text { Asylum seeker interview (duo) } \\
\text { Observation }\end{array}$ \\
\hline $\begin{array}{l}\text { Young Persons' } \\
\text { Group }\end{array}$ & $\begin{array}{l}\text { A thematic Social Inclusion Partnership to support } \\
\text { young people leaving institutional care around } \\
\text { housing, employment and training, health and } \\
\text { well-being, and social support. }\end{array}$ & $\begin{array}{l}\text { Service manager interview } \\
\text { AS group interview } \\
\text { Observation }\end{array}$ \\
\hline $\begin{array}{l}\text { Framework for } \\
\text { Dialogue } \\
\text { Group }\end{array}$ & $\begin{array}{l}\text { One of eight professionally led groups facilitated } \\
\text { and administrated by community development } \\
\text { workers from the public sector and the Charity. } \\
\text { Provided information and also a forum for AS to } \\
\text { influence the planning of services. }\end{array}$ & $\begin{array}{l}\text { Service manager interview } \times 2 \\
\quad(\mathrm{PSO} 2 \text { and PSO3) } \\
\text { Asylum seeker interviews } \times 6 \\
\text { Observation }\end{array}$ \\
\hline $\begin{array}{r}\text { Integration } \\
\text { Network }\end{array}$ & $\begin{array}{l}\text { One of ten such networks operating in the city. The } \\
\text { group is comprised of member from across the } \\
\text { public and NPVS who are responsible for } \\
\text { asylum seeker services. The group meets } \\
\text { regularly to plan services. }\end{array}$ & $\begin{array}{l}\text { Service manager interview } \times 4 \\
\quad(\text { VOAP, PSO1, PSO } 2, \\
\text { Church B) } \\
\text { Observation }\end{array}$ \\
\hline
\end{tabular}

Information and advice (73.8\%) was a key aspect of public service provision, followed by language courses $(50 \%)$ and drop-in centres $(40.5 \%)$.

Service providers from the public and NPV sectors alike showed a divergence away from the core service task to focus on more social welfare type services that would help to integrate asylum seekers in the Scottish society. For example, the Project Worker from the Accommodation Provider offered support and advice on an individual basis to ensure the well being of asylum seekers, going beyond his organisation's main objective of checking accommodation. Church A also referred asylum seekers onto other public service providers, depending upon need. 
Table 3 Stakeholder interview respondents

Stakeholder interview respondents

Charity Service Manager

Small Voluntary Organisation Service Manager

Local Authority Arms Length Company Service Manager

Small Charity Service Manager

Women's Voluntary Organisation Service Manager

Scottish Refugee Policy Forum Representative

Although respondents suggested they did less work around advocacy than when asylum seekers had first arrived in Glasgow, there was still a place for advocacy and larger NPVOs generally sat in a good position to raise concerns or lobby. The Charity, Humanitarian Organisation and Woman's Voluntary Organisation played multiple roles, delivering services, contributing to service planning and working on an adversarial basis to represent asylum seekers and campaign on their behalf. Respondents said that they worked to ensure that asylum seekers received appropriate services from public sector organisations and that structures were in place for integration. The Humanitarian Organisation, for example, provided an orientation service which was described as a 'key refugee service, which provides one to one volunteer support to asylum seekers or refugees to help them with the integration process, to help them to access statutory services...'

The perception around this adversarial role differed among respondents. Some public officials described this role as: 'Not helpful, not productive because this is an ideal opportunity for them, literally, to get up on their soapbox...' (Government Agency). Others considered it to result in more fruitful discussions which led to service improvements, so long as the role was played in a professional way; feet stamping and making demands were not appropriate.

... when you go into a meeting now and somebody gets up and starts to rail against the Borders Agency and the Government and you now kind of look at them go, really? You're talking nonsense. If you are a refugee in Glasgow and you want support and access in education, it's there. If you want support and access in employment, it's there. If you want support in improving integration, it's there. (Humanitarian Organisation)

The dual role of service provision and advocacy was also regarded as challenging in some cases:

I think sometimes there's been a bit of role confusion, because if somebody acts as a provider of a service and, if you like, takes the Prime Minister's shilling, if you like, then they are part of, like it or not, an operational partnership... And then if an organization stands back and then criticizes that, it can be difficult.... (Accommodation Provider Strategic Manager) 


\section{When Planning and Delivering Public Services, to What Extent Do NPVOs Work Across Organisational Boundaries and What Kind of Relationships Exist?}

A majority (83.3\%) of survey respondents said that they worked with NPVOs when providing services to asylum seekers. Of those, $31 \%$ said they did so during the development of policies, $78.6 \%$ said they did so during service delivery and $47.6 \%$ said they involved NPVOs after service delivery. Respondents were also asked to describe their relationships with NPVOs: two-thirds said they worked in partnerships $(61.9 \%)$ but networks followed at $50 \%$. Only $9.5 \%$ of organisations described their relationship with NPVOs as contractual.

In terms of co-management, the Scottish Government funded various NPVOs to deliver services for asylum seekers, ranging from support around integration to the provision of drop-in centres or arts and crafts activities. The Charity, for example, was partly funded to provide support services to asylum seekers and was also responsible for consulting asylum seekers on behalf of the Scottish Government.

There was only one clear example of a contractual relationship, with the Accommodation Provider working under a contract with the Government Agency to provide housing to asylum seekers. The contract was subject to 'huge financial penalties' for any mistakes on the part of the Accommodation Provider and this formed the basis of a strained relationship between the two parties.

We think we should work in partnership with them. It's more, you're the contractor; you signed a contract, get on with it... and they can make huge mistakes. No wee... big, big mistakes. And we can't do anything about it... the staff get a bit annoyed... (Accommodation Provider Service Manager).

The relationship was made more challenging by the geographical distance between the two parties and the sheer size of the Government Agency, which made effective communication difficult. The contract also had implications for the extent to which the Accommodation Provider could advocate on behalf of asylum seekers. Speaking about detention centres, the service manager said 'we were all moaning. The staff were moaning about it but we can't... We're the contractor'.

However, co-management was not restricted to government contracts. It was also found to exist between organisations delivering services on the ground. For example, the two churches provided shared crèche services to enable asylum seeker women to make use of other services. This relationship was described as unproblematic because both partners had the same aims: 'it does go quite smoothly because we're both going for the same thing'. However, other relationships were more strained. The Public Service Organisation and the Arm's Length Local Authority also worked in partnership to deliver a service aimed at promoting integration among young asylum seekers and the indigenous population, but the relationship was described as challenging, lacking clear lines of communication and trust.

Links across organisational boundaries and the exchange of information were crucial both to the asylum process and to the delivery of appropriate public services to meet individuals' needs. The Accommodation Provider and Churches spoke of 
sharing information with various statutory agencies and referring asylum seekers onto service providers in reaction to individual needs. Some relationships were more formal than others. Church B, for example, had not established any formal partnerships with statutory agencies, but exchanged information and advice as and when required.

... that lady today, she may have to be taken from the Housing Service or the Homelessness Service... to the Social Work Department, so therefore in that sense we're working with them but not in terms of partnership with them. We're really just using them...

Co-governance was demonstrated by the presence of service planning and delivery networks operating in the city.

Bodies such as the Accommodation Provider, the Scottish Government, the Government Agency and the Charity sat together on a Strategic Partnership Group to discuss policy at this level. Despite having access to strategic deliberations, one respondent complained that Scotland tended to be 'tagged on, rather than an integral part to that [policy] cycle' (Accommodation Provider Strategic Manager). The respondent suggested that effective structures need to be in place below the strategic groups: 'people need to form alliances and do preliminary work outside that group to make it work'.

The Government Agency respondent recognised that there 'should be' partnership working between operational staff and local agencies, but that such engagement often takes a back seat due to other work commitments and also if there are 'too many people working in too many work streams and in too many different jobs... [or in] a silo approach'. However, the Scottish Refugee Policy Forum, which represented various refugee community organisations, fed into the strategic level meeting the Government Agency regularly:

one of the things they do is they make the proposals, they make propositions, and another thing they do is to complain and be oppositional. And sometimes as a result of that, of both of those activities, things get changed.... (Charity)

The Scottish Stakeholders' Forum was 'led' by Government Agency in Glasgow and included the Scottish Government, Glasgow City Council, COSLA, Edinburgh City Council, the Scottish Refugee Council, British Red Cross, the Victims of Torture the Legal Practitioners' Forum, the International Office of Migration and Strathclyde Police. Although the Forum was used primarily to discuss national issues at a local level, it was also used it as a means of picking up local issues to be raised at national meetings.

A National Stakeholders Forum, held in London by the Government Agency, also existed to discuss issues pertinent to asylum seekers. With predominantly NPVOs sitting around the table, the Scottish Government was not party to the forum, although there was a representative from the Convention of Scottish Local Authorities. This forum was considered to show an adversity to work in silos and an attempt to recognise different levels of knowledge and information. However, there was criticism over the size of the group and the absence of pre-agenda which made it difficult to prepare and contribute effectively: 'so it tends to be, you get the 
papers, you turn up, there's presentations, there's discussions, agenda item moves onto the next one.' (Accommodation Provider Strategic Manager). Working on different levels was also described as challenging:

It's almost like three dimensional chess... You know those kiddie books you get about joining up the dots? Sometimes that's what it feels like, you know. You go from one meeting to another meeting and what you try and do is make the link and build onto the next stage ... (Humanitarian Organisation)

Various NPVOs and public sector agencies (such as Community Healthcare Partnerships) collaborated on ten Integration Networks (IN) operating across the city to create an integrated approach to service planning, delivery and evaluation. Public funds were distributed to the Networks via Community Planning Partnerships and Networks were responsible for developing their own Integration Plans: '...it comes from the bottom... These guys know what they're talking about because they do it day in day out... If it was any other way it simply wouldn't function.' (Voluntary Community Organisation Accommodation Provider)

The INs were established as a means of providing deeper forms of engagement, providing an opportunity for various organisations that represent asylum seekers to sit a round the table and contribute to the development of an operational strategy.

... that network then brings together an action plan, a kind of menu of activities for the year. And should ensure that menu is influenced and informed by asylum seeker service users... That you engage them effectively in the design of the services and you're checking those services off with service users. Are these the services that they want? Are they at the right time? Do they make sense to you? Do they work? And in that way, I think, you're going to get a much richer, much more effective grassroots involvement. (Community Planning Partnership)

Relevant organisations and agencies sitting around the table, sharing information and communicating with one another was said to improve service provision. However, the effectiveness of planning was dependent upon those present speaking up and raising pertinent issues.

... once the Plan's all done and dusted and it's all been agreed, somebody comes and says, 'Oh by the way, half the asylum seeking population have real Mental Health problems, so why's that not in the Plan...' Well, why did you not come to the Development Day, and you could have raised it then? (Public Service Organisation 2)

Although the INs were generally described as effective, networks were not necessarily continued on a day-to-day basis due to time pressures and financial constraints. This was particularly the case for smaller service providers: 'I think the difficulty for most people is time and resources now... you get caught up with your own sort of thing'. (Small Charity). However, other respondents described networking as a core element of their job. Networking at the operational level was important for the adult literacy service manager from the Development Organisation, who was looking to build links, exchange information and promote 
interest in services: 'I go into all the integration networks as well... to let people know who I am, which services I've got and through that I'm getting referrals'.

The INs had a dual role, being used both as a means of planning services across organisational boundaries and also connecting to 'Framework for Dialogue' groups operating at the neighbourhood level. Eight such groups were in operation across Glasgow and acted both as 'information provision networks' and 'consultation mechanisms'. Policy makers and service managers alike discussed the benefits of creating dialogue asylum seekers and avoiding duplication of work or overengagement.

... individual agencies engage with a particular client group and then two months later a different agency will engage with the same client group... And all that does is confuse the client group. So we're a partnership, so we are insisting on collective engagement... And that hopefully will... reduce the amount of engagement but will strengthen the quality of engagement. (Community Planning Partnership)

FFDGS and IN were described as having 'conterminous boundaries', with each sharing the function of 'building bonds' (Charity). However, time constraints, resourcing issues and language barriers were all recognised as barriers that impede the involvement of FFD during IN planning sessions. Thus, there was a reliance on the community development workers to act as a conduit between the two structures. However, one manager recognised that such a role may result in them being viewed 'as gatekeepers or seem to be keeping people out' (Public Service Organisation 2).

FFDGs were also important mechanisms through which operational considerations could be filtered up to strategic decision-making level, as they had direct links with the Scottish Refugee Policy Forum and the Charity which sat on various strategic groups.

So what you've got now on the basic level is people who get together on a neighbourhood level and they can in some cases take issues up to service level locally or at a bigger level. And they can take issues up with government in various ways, both at the Scottish level and the Westminster level. (Charity)

\section{In Practice, What Makes Inter-organisational Relationships Work?}

Respondents considered the consequences for their business and the sustainability of working together, not simply whether there would be positive implications for service users. Policy makers, for example, identified reduced public spending as a trigger for increased partnership working. One respondent suggested that reduced public spending would likely result in bigger contracts from government bodies which the NPVS could only effectively compete for through collaborative working. Inter-organisational working was also described by service managers as a requirement of funding, such as the Development Organisation's adult literacy service.

The geography of Scotland and Glasgow in particular was described as conducive to partnership working: 'it's the biggest village in the planet... I mean 
if you're stuck with something, you'd pick up the phone to, who you would see as a colleague, because you used to work with them'. (Humanitarian Organisation). Various respondents also mentioned a Scottish mindset towards and a history of inter-organisational working. However, this was particularly challenging during the early days of a service, with the need to establish effective services prioritised over networking and relationship-building:

It was grim to begin with. We were at each other's throats... And it took a wee while to kind of introduce some sort of agreed mechanism that we could start communicating. (Local Authority Arm's Length Company)

I didn't go out proactively to the Scottish Government, to Glasgow City Council. We were very eager, heads down, kind of wanting to develop what we felt were really good resources. (Humanitarian Organisation).

One of the challenges of inter-organisational working was that organisations might fear other organisations overstepping the boundaries and taking their responsibilities: 'There's always a fear, particularly when you work with partners, is that everybody will start wandering into everybody else's patch'. (Local Authority Arm's Length Company). This was associated with a fear of losing funding as a result of other players taking over core functions and therefore having a negative impact upon the lifespan of the organisation.

Individual personal relationships were important to co-management and cogovernance. Respondents described going to college together or how many people started out in the Charity as colleagues and had since moved to various other organisations operating in the field: 'I knew X at college in the 1980s... And I guess as a Community Development service, we are such a shrinking band of workers, that we kind of cling to each other'. (Public Service Organisation 2).

Trust was considered to be a central element which could make or break relationships.

the key to a partnership, if you can get trust... You can have one or two partners that you don't particularly like, but can tolerate. If you all hated one another, it would just fall apart and we've seen it at certain times. (Local Authority Arm's Length Company)

However, there were examples of mistrust for counterparts across organisational boundaries. There was some concern among smaller NPVOs that requests for interorganisational working arose out of a desire to 'piggy back on your success' (Church B). Another respondent described a situation where organisations working with asylum seekers act as gatekeepers, until they are sure of the benefit that might result from inter-organisational working.

You've got to have a good relationship with the organizers before you can actually get to the service users because if they don't like you they're like 'well, what can you do for us?' So we need to be very sensitive and very aware of how... establishing our links and then building up trust and then going out to deliver. (Women's Voluntary Organisation) 
Respondents spoke of the benefits of face-to-face interactions in developing improved working relationships across organisational boundaries and the dangers that no personal contact for effective collaborative working. One respondent recognised that inter-organisational relationships did not exist in constant harmony, but 'understand[ing] each other's position' and communication ensured that disagreements did not result in 'the whole... edifice tumbling down'. (Accommodation Provider). Little trust was found to exist between organisations contracted to work for the Government Agency, with limited face-to-face contact or indeed clear lines of communication existing on the operational level.

In contrast, the relationship between the Accommodation Provider and Charity appeared strong. At the strategic level, the close relationship between two senior members across the organisational boundaries paved the way for relationships throughout the two organisations. Respondents noted the Accommodation Provider's early reluctance to inter-organisational working which had since changed as a result of having established core services and also the approach of the senior manager:

I think there's suddenly been a realisation that oh actually, my goodness, there's a broader voluntary sector who have been working with this community, who've been doing a lot of very strong and very good work. (Humanitarian Organisation)

This supported relationships at the operational level, with front-line staff sharing information and working together to meet the service needs of clients.

\section{Discussion and Conclusions}

This study has investigated whether asylum seeker integration is fostered through inter-organisational relationships between non-profit and voluntary organisations (NPVOs) and government agencies. It considered three subquestions: What role do NPVOs play in the planning and delivery of public services? When planning and delivering public services, to what extent do NPVOs work across organisational boundaries and what kind of relationships exist? And in practice, what makes interorganisational relationships work? The findings have implications for both theory and practice which will be discussed below.

\section{Implications for Theory}

The social, political and legal backdrop faced by asylum seekers makes integration challenging. Asylum seekers are situated in a socially disadvantaged position and cannot participate in paid employment, but are provided with accommodation, education and health, all of which fall under Ager and Strang's (2008) framework of integration. This research has also shown how asylum seeker integration has been promoted in Scotland, highlighting certain important factors which were not included in Ager and Strang's framework, such as policy direction, the disposition 
of organisations providing public services (towards both integration and interorganisational working) and geography.

Despite their socially disadvantaged position, the political context in Scotland and specifically the promotion of integration by the Scottish Government had filtered down to the operational level, as had the propensity for inter-organisational working through co-management and co-governance.

The NPVS was invariably described by case study respondents as playing a key role in planning and delivering public services to asylum seekers. The survey findings showed a high regard for NPVOs which were generally viewed as adding value to public services and contributing to their effectiveness, confirming the arguments made in the literature (Wren 2007). The goal of integration underpinned many of the services provided by NPVOs, such as English language provision and building relationships among asylum seekers and with the indigenous population (Ager and Strang 2008). Some organisations, such as the Accommodation Provider and Church A, also diverged from core tasks to promote integration.

The geography, along with established structures, clear organisational remits and personal relationships created a viable environment for inter-organisational relationships. Indeed, asylum seeker services were well established in Glasgow, making it easier for organisations to work together. Respondents suggested that there was less need for wrangling over substantive issues because agencies across sectors had a history of working together and have laid the foundations of asylum seeker services down together. There was less of a role for advocacy, but larger NPVOs generally sat in a good position to raise concerns or lobby against issues, despite this strong undercurrent of inter-organisational working.

\section{Implications for Practice}

This study has also contributed to practice. It has suggested a key role for the NPVS in the provision of public services for asylum seekers and also underlined the importance of working together across organisational boundaries to plan and deliver services based on needs. Various NPVOs acted as mediating structures, helping asylum seekers access public services, another element of Ager and Strang's framework of integration. The NPVS was also a vital cog in the chain which created dialogue between asylum seekers and both public service organisations and policy makers. The Charity, for example, played a central role being funded by the Scottish Government to consult asylum seekers and also acting as a key link, connecting other NPVOs with strategic players.

Building and sustaining inter-organisational relationships was deemed necessary for effective partnership working and linked to this, the successful delivery of services to meet needs, one of which was identified as integration. This has important implications for public service management and how inter-organisational relationships are managed to improve service production. Individual personal relationships and trust were essential to co-management and co-governance (Ring and Van de Ven 1992; Gulati 1995; Zaheer et al. 1998).

Through co-management, there was a need to exchange and share information about asylum seekers and also refer them onto other public services to ensure 
complex needs were met. On the whole, the relationships uncovered by the research were good, although there were some instances of mistrust and poor communication which made working together challenging. Personal relationships between service managers across organisational boundaries were of particular importance in facilitating co-management and co-governance. Trust was described as developing over time through frequent and close interaction (Gulati 1995; Nooteboom et al. 1997; Tsai and Ghoshal 1998), with service managers having been to college together or working together previously.

Three models of co-governance were apparent at the strategic, operational and neighbourhood levels. At the strategic level, good relationships among key players in Scotland such as the Charity and Accommodation Provider facilitated interorganisational working. Strong personal relationships between individuals across organisational boundaries and particularly between those at the top who were responsible for steering the direction of the organisation were important. By contrast, the relationship with the Government Agency was described as more fraught. The distance and lack of face-to-face contact made relationships difficult and respondents described Scotland as being tagged onto policy rather than integral to it.

At the operational level, Integration Networks formed joint planning sessions to draw together expertise, knowledge and resources with the aim of providing needsled services and promoting integration into Scottish society. However, such interorganisational relationships were not replicated on a day-to-day basis given time constraints and resource issues. The Framework for Dialogue Groups at the neighbourhood level were essential, supporting asylum seeker integration by providing a structure to facilitate service user participation (Pestoff 2012). The FFDGs fed into Integration Networks, offering a means by which to be connected to and informed by services users and also provided public service providers a mechanism through which to directly consult asylum seekers.

Co-management and co-governance were not, however, operating in silos, with complexity and cross over between the two relationships. Relationships were dynamic, with organisations working on Integration Networks to plan services at the operational level (co-governance) and concurrently working together on smaller projects to deliver services together (co-management) or working with other organisations on an informal basis to refer asylum seekers with specific needs. They were also challenging in terms of time and resources and where relationships between service managers across organisational boundaries lacked trust and communication.

This study has added to theory by showing that asylum seeker integration can indeed be promoted through co-management and co-governance, but that other factors such as government policy, geography, established services, personal relationships and structures of participation are fundamental to both integration and inter-organisational relationships. In Glasgow, the NPVS played a central role in planning and delivering services and contributing to strategic decision-making (particularly in Scotland). Its involvement facilitated the meeting of complex asylum seekers needs, one of which was integration. There was clear evidence of NPVOs working across organisational boundaries in the pursuit of each of these 
roles. Ultimately, this has implications for practice and specifically how interorganisational relationships might be best managed to promote the necessary levels of communication and trust to facilitate effective co-management and cogovernance. To better understand how these relationships might be managed, the services management literature might offer useful theoretical grounding: this is an area which future research might seek to explore.

\section{Compliance with Ethical Standards}

Conflict of interest The authors declare that they have no conflict of interest.

Open Access This article is distributed under the terms of the Creative Commons Attribution 4.0 International License (http://creativecommons.org/licenses/by/4.0/), which permits unrestricted use, distribution, and reproduction in any medium, provided you give appropriate credit to the original author(s) and the source, provide a link to the Creative Commons license, and indicate if changes were made.

\section{References}

Ager, A., \& Strang, A. (2008). Understanding integration: A conceptual framework. Journal of Refugee Studies, 21(2), 166-191.

Aiken, M., \& Hage, J. (1968). Organizational interdependence and intra-organizational structure. American Sociological Review, 33(6), 912-930.

Berger, P. L., \& Neuhaus, R. J. (1978). To empower people: the role of mediating structures in public policy. Washington DC: American Enterprise for Public Policy Research.

Bloch, A. (2000). Refugee settlement in Britain: The impact of policy on participation. Journal of Ethnic and Migration Studies, 26(1), 75-88.

Bloch, A., \& Schuster, L. (2002). Asylum and welfare: Contemporary debate. Critical Social Policy, 22, 393-414.

Bode, I. (2006). Disorganized welfare mixes: voluntary agencies and new governance regimes in Western Europe. Journal of European Social Policy, 16(4), 346-359.

Brandsen, T., \& Pestoff, V. (2006). Co-production, the third sector and the delivery of public services. Public Management Review, 8(4), 493-501.

Brandsen, T., \& von Hout, E. (2006). Co-management in public service networks: The organizational effects. Public Management Review, 8(4), 537-549.

Brenton, M. (1985). The voluntary sector in British social services. London: Longman.

Deakin, N. (2001). Putting narrow-mindedness out of countenance: The UK voluntary sector in the new millennium. In A. Anheier \& J. Kendall (Eds.), Third sector policy at the crossroads. London: Routledge.

Griffiths, D., Sigona, N., \& Zetter, R. (2006). Integrative paradigms, marginal reality: Refugee community organisations and dispersal in Britain. Journal of Ethnic and Migration Studies, 32(5), 881-898.

Gulati, R. (1995). 'Does familiarity breed trust? The implications of repeated ties for contractual choice in alliances'. The Academy of Management Journal, 38(1), 85-112.

Haikio, L. (2010). The diversity of citizenship and democracy in local management Reform. Public Management Review, 12(3), 363-384.

Haugh, H., \& Kitson, M. (2007). The third way and the third sector: New Labour's economic policy and the social economy. Cambridge Journal of Economics, 31, 973-994.

Kale, P., Singh, H., \& Perlmutter, H. (2000). Learning and protection of proprietary assets in strategic alliances. Strategic Management Journal, 21(3), 217-237.

Kearns, A. (1995). Active citizenship and local governance: political and geographical dimensions. Political Geography, 14(2), 155-175. 
Kelly, J. (2007). Reforming public services in the UK: Bringing in the third sector. Public Administration, 85(4), 1003-1022.

Klijn, E. H. (2008). Governance and governance networks in Europe. Public Management Review, 10(4), $505-525$.

Klijn, E. H., \& Koppenjan, J. F. M. (2000). Public management and policy networks: foundations of a network approach to governance. Public Management, 2(2), 135-158.

Levine, S., \& White, P. E. (1961). Exchange as a conceptual framework for the study of interorganizational relationships. Administrative Science Quarterly, 5(4), 583-601.

Morison, J. (2000). 'The government-voluntary sector compacts: Governance, governmentality and civil society'. Journal of Law and Society, 27(1), 98-132.

Newman, J. (2007). The double dynamics of activation: institutions, citizens and the remaking of welfare governance. International Journal of Sociology and Social policy, 27(9/10), 364-375.

Nooteboom, B., Berger, H., \& Noorderhaven, N. G. (1997). Effects of trust and governance on relational risk. The Academy of Management Journal, 40(2), 308-338.

Pestoff, V. (2012). Co-production and third sector social services in Europe: Some concepts and evidence. Voluntas, 23(4), 1102-1118.

Pestoff, V., Osborne, S. P., \& Brandsen, T. (2006). Patterns of co-production in public services. Public Management Review, 8(4), 591-595.

Pfeffer, J., \& Nowak, P. (1976). Joint ventures and interorganizational interdependence. Administrative Science Quarterly, 21(3), 398-418.

Rhodes, R. A. W. (1997). Understanding governance: policy networks, governance, reflexivity and accountability. Maidenhead: Open University Press.

Ring, S. S., \& Van de Ven, A. H. (1992). Structuring cooperative relationships between organization. Strategic Management Journal, 13, 483-498.

Sales, R. (2002). 'The deserving and undeserving? Refugees, asylum seekers and welfare in Britain'. Critical Social Policy, 22, 456-478.

Schmid, H. (2003). Rethinking the policy of contracting out social services to non-governmental organizations: lessons and dilemmas. Public Management Review, 5(3), 307-323.

Scottish Government. (2006). Transforming public services: The next phase of reform. Edinburgh: Scottish Government.

Scottish Government. (2008). Race equality statement. Edinburgh: Scottish Government.

Sicilia, M., Guarini, E., Sancino, A., Andreani, M., \& Ruffini, R. (2016). Public services management and co-production in multi-level governance settings. International Review of Administrative Sciences, 82, 8-27.

Sim, D., \& Bowes, A. (2007). Asylum Seekers in Scotland: The Accommodation of Diversity. Social Policy \& Administration, 41(7), 729-746.

Somerville, P., \& Haines, N. (2008). Prospects for local co-governance. Local Government Studies, 34(1), 61-79.

Tsai, W., \& Ghoshal, S. (1998). Social capital and value creation: the role of intrafirm networks. The Academy of Management Journal, 41(4), 464-476.

Tsukamoto, I., \& Nishimura, M. (2006). The emergence of local non-profit-Government partnerships and the role of intermediary organizations in Japan. Public Management Review, 8(4), 567-581.

Vidal, I. (2006). Reflections on the market, networking and trust. Public Management Review, 8(4), 583-589.

Wren, K. (2007). Supporting asylum seekers and refugees in Glasgow: The role of multi-agency networks. Journal of Refugee Studies, 20(3), 391-413.

Zaheer, A., McEvily, B., \& Perrone, V. (1998). 'Does trust matter? Exploring the effects of interorganizational and interpersonal trust on performance'. Organization Science, 9(2), 141-159. 